\title{
EXOC7 Gene
}

National Cancer Institute

\section{Source}

National Cancer Institute. EXOC7 Gene. NCI Thesaurus. Code C113126.

This gene is involved in vesicle exocytosis. 